\title{
Lactococcus lactis: LAB model organism for bacteria-mediated therapeutic strategies
}

\author{
Hanis Faudzia , Habibah Faroque ${ }^{a}$, Suet Lin Chia ${ }^{\text {b,c }}$, Raha Abdul Rahima, Sarah Othman ${ }^{a^{*}}$ \\ ${ }^{a}$ Department of Cell and Molecular Biology, Faculty of Biotechnology and Biomolecular Sciences, Unive rsiti Putra Malaysia, 43400 \\ UPM Serdang, Selangor, Malaysia \\ ${ }^{b}$ Department of Microbiology, Faculty of Biotechnology and Biomolecular Sciences, Universiti Putra Malaysia, 43400 UPM \\ Serdang, Selangor, Malaysia \\ 'Institute of Bioscience, Universiti Putra Malaysia, 43400 UPM Serdang, Selangor, Malaysia
}

Received 20th April 2018/ Accepted 12th July 2018

\begin{abstract}
Lactococcus lactis is a well-characterized, food-grade lactic acid bacterium (LAB) with generally recognized as safe (GRAS) status. Better understanding of this bacterium at a molecular level has led to the development of unprecedented genetic tools that enable the expression of heterologous proteins. Subsequently, the ability of $L$. lactis to express and deliver these proteins to eukaryotic hosts presents a promising approach to achieve potent treatments for various diseases. Here, we have reviewed the characteristics of $L$. lactis and the expression systems established for this LAB model organism. We also described the experimental applications of $L$. lactis in disease therapy, especially its role as a vector in vaccination strategies.
\end{abstract}

Keywords: bactofection, lactic acid bacteria, Lactococcus lactis, vaccine, vector

\section{INTRODUCTION}

\section{Background}

During the 90's, lactic acid bacteria (LAB) started to become popular starter cultures for the production of dairy and fermented food (Konings, 2000). This is particularly due to their ability to produce lactic acid as a major end product of carbohydrate fermentation (Kandler, 1983). Owing to their long history of use in food production, LAB have been proven as safe for human consumption and were certified as generally recognized as safe (GRAS) organisms by the US Food and Drugs Administration (FDA) (Kolida and Gibson, 2011). Currently, 13 genera have been classified under the LAB group, which include Lactococcus, Lactobacillus, Streptococcus, Pediococcus, Paralactobacillus, Enterococcus, Carnobacterium, Lactosphaera, Leuconostoc, Oenococcus,
Tetragenococcus, Weisella, and Vagococcus (Stiles and Holzapfel, 1997).

To date, efforts have been made to achieve a better understanding of $\mathrm{LAB}$ and to advance their application in health and nutrition. Improved knowledge of LAB has contributed to the development of heterologous protein expression systems, coupled with gene transfer mechanisms that have led to the employment of LAB as delivery agents for the treatment of diseases. Among them, Lactococcus lactis is the mostcharacterized LAB organism which has been extensively studied for biomedical applications. In this review, we discuss the properties of $L$. lactis, which made it an excellent LAB model. We also describe several $L$. lactis-based expression and delivery systems available, as well as a summary

* Author for correspondence: Dr. Siti Sarah Othman, Senior Lecturer, Department of Cell and Molecular Biology, Faculty of Biotechnology and Biomolecular Sciences, Universiti Putra Malaysia, 43400 UPM Serdang, Selangor, Malaysia. Email - sarahothman@upm.edu.my 
on the current $L$. lactis treatment strategies, particularly DNA vaccination.

\section{Uses and importance of LAB}

Major advancements in bacterial taxonomy tools and molecular biology tools in the past decades have led to revolutionary growth in studies involving the isolation and characterization of new LAB strains from various sources (Abushelaibi et al., 2017; Guo et al., 2010; Rubio et al., 2014; Zoumpopoulou et al., 2017). Morphologically, LAB are found in either rod or coccus shape and may exist as single cells or in chains (Settanni and Moschetti, 2010). Past studies have identified LAB as great starter cultures and additives for biopreservation of food, based on their ability to produce natural bacteriocins (Hirsch, 1951; Sashihara et al., 2000; Sawa et al., 2010, 2013) with antimicrobial effects against other strains, such as Listeria monocytogenes (Allende et al., 2007; Amezquita and Brashears, 2002; Perin and Nero, 2014), methicillin-resistant Staphylococcus aureus (Okuda et al., 2013), and Salmonella (Kim et al., 2015; Stevens et al., 1991) Furthermore, the production of antibacterial proteins gives $\mathrm{LAB}$ a survival advantage over other strains and helps to maintain the equilibrium of the gastrointestinal tract (GIT) microflora, hence revealing their probiotic potentials. Initially described by Lilly and Stillwell (1965), probiotics is now used to refer to microorganisms that can confer health benefits to the host, which may include cancer prevention, decreased risks of inflammatory bowel syndromes and gastrointestinal infections, immune modulation, and relief of lactose intolerance symptoms, diarrhoea, and constipation (Salminen et al., 1999; Schrezenmeir and de Vrese, 2001). The probiotic potential of LAB is also a result of their tolerance towards low $\mathrm{pH}$ and their ability to persist within the harsh, acidic environment of the GIT. Although acid tolerance is reported to be strain-dependent, several LAB, mostly belonging to the genus Lactobacillus, have been shown to display this characteristic (Goldin et al., 1992; Jacobsen et al., 1999; Oozeer et al., 2006; Rubio et al., 2014).

\section{Lactococcus lactis as a model organism of LAB}

\subsection{Characteristics}

The first bacterial pure culture of Lactococcus lactis (previously known as Bacterium lactis) was isolated from boiled milk, in 1873 by Joseph Lister (Stiles and Holzapfel, 1997). Subsequently, L. lactis became an important starter culture in the food industry, particularly for the production of cheese, milk, and buttermilk (Leroy and de Vuyst, 2004). $L$. lactis is described as a non-pathogenic, mesophilic, coccus bacterium of about 0.5 to 1 $\mu \mathrm{m}$ diameter (Teuber and Geis, 2006). This fermentative anaerobic bacterium is Grampositive, and is therefore, less likely to induce immunogenic response when compared to Gramnegative bacteria such as Escherichia coli (Rueda et al., 2014; Salminen et al., 1998). Although L. lactis does not naturally colonize the digestive tract, the presence of its strains among the GIT microflora has been acknowledged in several studies (Grahn et al., 1994; Klijn, Weerkamp, and de Vos, 1995; Schlundt et al., 1994).

In many instances, it is worth noting that $L$. lactis is capable of adhering to intestinal cells. Using direct microscopic evaluation of Gramstained samples, Lehto and Salminen (1997) reported that $L$. lactis subsp. cremoris ARH 74 is capable of adhering to human colorectal cancer cell line, Caco-2. The percentage of adhesion was determined as $16 \%$, slightly higher than that of the positive control, Lactobacillus GG strain (Lehto and Salminen, 1997). Likewise, Kimoto et al. (1999) demonstrated that six out of nine L. lactis strains tested, are capable of adhering to Caco-2 cells. Among them, L. lactis subsp. lactis NIAI527 displayed the greatest level of adhesion (Kimoto et al., 1999). Further investigations revealed that this strain could withstand low $\mathrm{pH}$ and bile, according to the number of colony forming units per millilitre $(\mathrm{CFU} / \mathrm{ml})$ obtained upon incubation for 30 minutes at $\mathrm{pH} 2.5$ and under $0.5 \%$ oxgall, respectively (Kimoto et al., 1999). Meanwhile, Ouwehand et al. (1999) have shown that L. lactis subsp. cremoris is able to adhere well to the mucus layer of human intestine. It was proposed by the authors that the study used mucus instead of intestinal cells in order to provide a better 
representation of in vivo intestinal cells, which are typically covered by the mucus layer.

Like most LAB strains, L. lactis is also known to produce bacteriocins such as nisin (Biscola et al., 2013; Kuipers et al., 1993) and lactococcin (Alegría et al., 2010; Holo, Nilssen, and Nes, 1991; Nissen-meyer, Holo, and Havarstein, 1992), effective against a considerate range of microorganisms, such as Salmonella, Listeria, and Enterococcus. Thus, based on these evidences, $L$. lactis is a very likely candidate for probiotic applications, comparable to Lactobacillus.

\subsection{Genetic tools}

As a result of extensive molecular studies of $L$. lactis and its subspecies, today, vast information regarding the genome of several $L$. lactis strains is available (Bolotin et al., 2001; Bolotin et al., 1999; Wegmann et al., 2007). In addition, numerous reports on the genomic characterization of novel L. lactis strains isolated from a myriad of sources have also been published (Fernández et al., 2011; Gao et al., 2011; Siezen et al., 2010). At present, improved understanding of $L$. lactis genome has provided a platform for the modelling of this bacterium's metabolic pathways (Flahaut et al., 2013; Guedon et al., 2005; Oliveira, Nielsen, and Förster, 2005). Consequently, this wealth of knowledge has led to the development of a wide range of genetic tools for $L$. lactis, which comprises of gene transfer and gene knockout mechanisms, construction of novel lactococcalderived vectors, and establishment of regulated gene expression systems.

The greatest progress was met through the development of nisin-controlled gene expression (NICE) system, in which the expression of any gene placed under the control of $\mathrm{P}_{n i s \mathrm{~A}}$ promoter is induced by the addition of the substrate, nisin (de Ruyter et al., 1996; de Ruyter, Kuipers, and de Vos, 1996). Upon further evaluation, the incorporation of the signal transduction genes, nis $\mathrm{R}$ and $n i s \mathrm{~K}$, into the chromosome of $L$. lactis subsp. cremoris MG1363, has successfully generated the NZ9000 strain, a common host for the NICE system (Kuipers et al., 1998). The overview of regulated protein expression by NICE system is illustrated in Figure 1.

Apart from regulated gene expression systems, several other genetic tools have been developed in $L$. lactis to enhance bacterial uptake by host cells and to facilitate DNA delivery. For instance, Innocentin et al. (2009) reported that the development of $L$. lactis expressing either fibronectin binding protein A (FnBPA) of $S$. aureus or internalin A (InlA) of L. monocytogenes managed to improve the rate of $L$. lactis internalization into Caco-2 cells. Earlier, it was identified that the proteins FnBPA and InlA are involved in promoting invasion of $S$. aureus and $L$. monocytogenes, respectively (Dziewanowska et al., 1999; Lecuit et al., 1997). Similarly, Yagnik et al. (2017) designed a recombinant $L$. lactis expressing InlA to enhance the delivery of the plasmid pPERDBY, carrying a gene coding for enhanced green fluorescent protein (EGFP) to Caco-2 cells. Despite previous success in demonstrating that non-invasive $L$. lactis was capable of delivering the same plasmid into $\mathrm{CHO}-\mathrm{K} 1$ and $\mathrm{Caco}-2$ cells (Yagnik, Padh, and Desai, 2016), the incorporation of InlA expression has yielded three times greater expression of EGFP by Caco- 2 cells (Yagnik et al., 2017). Hence, it was proposed that this system could be applied for L. lactis-mediated treatment approaches, for enhanced therapeutic efficacy.

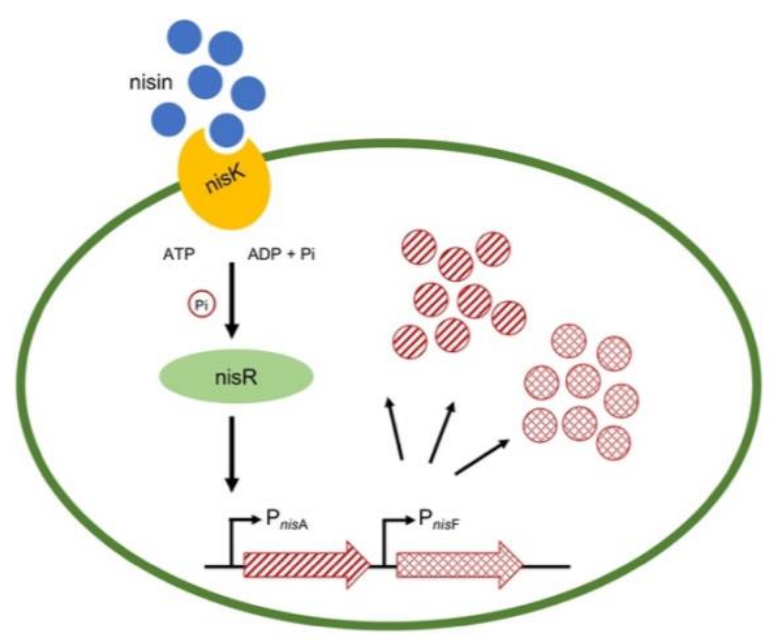

Figure 1. Schematic diagram of NICE system in L. lactis. Stimulation by extracellular nisin causes the histidine kinase, nisK, to undergo autophosphorylation and subsequently mediate phospho-transfer to the response regulator, nisR. This will then induce the transcription of genes under the inducible promoters, $\mathrm{P}_{\text {nis }}$ and $\mathrm{P}_{\text {nis } \mathrm{F}}$. 
In summary, the access to a complete characterization of $L$. lactis genome has provided substantial understanding of this bacterium's molecular biology and has inspired the development of state-of-the-art genetic expression systems, which in the future, could be replicated in other microorganisms, including other LAB strains. With a diverse array of genetic tools to choose from, L. lactis can be easily manipulated for biological and medical applications, ergo considered an excellent model of LAB.

\subsection{Therapeutic strategies using $L$. lactis}

The earliest report on tumor regression in cancer patients as a result of bacterial infection was described in 1813, involving Clostridium perfringens (Mowday et al., 2016). Several decades later, William Coley's work on a vaccine derived from Streptococcus pyogenes and Serratia marcescens for the treatment of cancer (Richardson et al., 1999) received enormous attention and has encouraged researchers to look into the role of bacteria for the treatment of diseases. As a result, several treatment strategies such as gene therapy and DNA vaccination have implemented the use of bacteria as delivery vectors. It has also been suggested that the employment of bacterial vectors could overcome the limitations of current DNA-based therapies. Through a process known as bactofection, bacteria could mediate DNA delivery into the host cells, thus enhancing the rate of gene transfer and enable the expression of heterologous proteins (Pálffy et al., 2006). Furthermore, this process can be manipulated to achieve specific or selective targeted treatments, which could be useful against a variety of diseases. Unlike conventional treatments, immunization via bacterial vectors are relatively simple and costeffective (Delany et al., 2014).

Over the years, live bacteria, including Salmonella (Agorio et al., 2007; Yang et al., 2010), Listeria (Pilgrim et al., 2003; van Pijkeren et al., 2010), Shigella (Galmbacher et al., 2010), and Pasteurella (Kamal et al., 2017; Othman, Parton, and Coote, 2012) have been frequently tested as potential vector candidates. Unfortunately, the use of these bacteria, despite attenuated, is faced with criticisms from the lack of evidence to prove their safety. Therefore, the GRAS food-grade $L$. lactis may be a potential alternative to achieve maximum treatment efficacy, while maintaining minimal health risks.

One of the earliest investigations on oral immunization using L. lactis was reported by Iwaki et al. (1990), using a recombinant L. lactis expressing a surface protein antigen (PAc) from Streptococcus mutans. Upon oral immunization with this recombinant strain, significant induction of PAc-specific immunoglobulin A ( $\operatorname{IgA}$ ) and $\operatorname{IgG}$ were detected in saliva samples of mice, implying that this recombinant strain may be a potent immunization strategy for dental caries (Iwaki et al., 1990).

Since then, a considerable amount of researches have focused on the expression of tetanus toxin fragment C (TTFC) derived from Clostridium tetani, to elicit immune responses. In one study, Norton et al. (1997) showed that mice nasally immunized with recombinant $L$. lactis experienced an elevated production of IgG1 and IgG2b in response to TTFC. Also using a mouse model, Robinson et al. (1997) reported similar findings upon oral administration of $L$. lactis constitutively expressing TTFC. Meanwhile, Steidler et al. (1998) has successfully constructed a recombinant $L$. lactis co-expressing TTFC with cytokines to boost the immune response. Following intranasal immunization, co-expression of interleukin-2 (IL-2) or IL-6 with TTFC resulted in greater levels of TTFC-specific IgA and IgG production (Steidler et al., 1998). Interestingly, further analysis on the different administration routes of TTFC-expressing $L$. lactis and the resulting cellular responses have revealed that intragastric and intranasal immunization contributed to comparable levels of IgG1 and $\mathrm{IgG} 2 \mathrm{a}$, but is predominantly composed of $\mathrm{IgG} 1$ when induced via intraperitoneal route (Robinson et al., 2004). In other words, the route of administration of recombinant $L$. lactis may be an important determining factor to trigger the desired immune responses of the host.

In other investigations, immunizations with recombinant $L$. lactis were designed to combat infections from a variety of pathogens. In 2005, Miyoshi et al. (2014) designed a recombinant $L$. lactis, capable of secreting Brucella abortus heatshock protein, GroEL, under the regulation of NICE system. Using the same expression system, Pontes et al. (2003) previously developed an $L$. 
lactis strain producing L7/L12 ribosomal protein to provide immunity towards brucellosis. For vaccinations against Helicobacter pylori infections, the incorporation of a vital virulence factor during gastric colonization, urease subunit beta (ureB), have been widely reported (Chen et al., 2006; Lee et al., 2001; Zhang et al., 2014). Although initially Lee et al. (2001) claimed that ureB failed to give immunoprotective levels of antibody production, findings from other studies have been quite favourable and $L$. lactis was concluded as a promising vector for anti-H. pylori immunization strategies. Apart from that, L. lactis has been genetically modified to express listeriolysin $\mathrm{O}$ (LLO) for intraperitoneal immunization acting against $L$. monocytogenes infections (Bahey-El-Din et al., 2008, 2010). The expression of LLO by L. lactis has successfully induced the generation of $\mathrm{IgG} 1$ and $\operatorname{IgG} 2 \mathrm{a}$, along with an increase of $\mathrm{CD}^{+}$ responses (Bahey-El-Din et al., 2008). In an attempt to refine the $L$. monocytogenes vaccination strategy, L. lactis was transformed with a plasmid harbouring genes encoding for LLO and listerial antigen, P60 (Bahey-El-Din et al., 2010). Even though no remarkable improvement was observed, it was suggested that the level of P60 were too low and may require additional optimization.

For vaccination against viruses, $L$. lactis has been tested to deliver viral antigens from H1N1 virus, human immunodeficiency virus (HIV), and human papilloma virus (HPV), among others. The most encouraging results were seen when $L$. lactis was designed to express E7 oncoprotein of HPV type 16 (HPV-16) for cervical cancer vaccines. The constitutive production of $\mathrm{E} 7$ protein was previously recognized in cervical carcinomas (Mclaughlin-drubin and Münger, 2009), and recombinant $L$. lactis expressing this protein has been developed to deliver the antigen in mouse models. According to BermúdezHumarán et al. (2004), L. lactis expressing E7 protein under an induced system generated significantly greater levels of IL-2 and interferon gamma (IFN $\gamma)$ when compared to a constitutive expression system. The different cellular localizations of E7 production also evoked different levels of immune response, with the highest response obtained when E7 protein expression was targeted to the cell wall. This HPV-16 vaccination strategy was later improvised by utilizing $L$. lactis expressing both a cell wallanchored E7 protein with IL-2 to provide a more potent and long-lasting immunity against HPVassociated cervical cancers (Bermúdez-Humarán et al., 2005). Other antigens and proteins that have been expressed and delivered by L. lactis in animal and in vitro models are outlined in Table 1 . This list includes the expression of carcinoembryogenic antigen (CEA) (Zhang et al. 2016a), anti-tumor necrosis factor (TNF) (Bernstein, Ho, and Lees, 2010), and various cytokines (Martín et al., 2014; Shigemori et al., 2017; Souza et al., 2016) for the treatment of cancers and inflammatory bowel diseases.

\section{Risks and concerns}

It is commonly acknowledged that $L$. lactis is an attractive vaccine vehicle for DNA and protein delivery. However, its use have not been fully exploited due to the perception that it is less effective compared to pathogenic microorganisms, based on the non-invasive nature of this bacterium. As previously discussed, invasive recombinant $L$. lactis strains have been constructed through the expression of invasive proteins. Unfortunately, the incorporation of these proteins are feared to render the strains pathogenic. Furthermore, the use of geneticallymodified strains may also present new challenges in terms of antibiotic resistance and gene transfer. In vitro, antibiotic resistant genes are often incorporated into genetic components such as plasmid DNA, to function as selectable markers. Although useful for an easy method of selection, these genes may give rise to resistant strains and could potentially transfer to other bacterial strains (Davison, 1999). Since the antibiotic resistance crisis is already a global threat that adds to the health and economic burden of the global population, it is feared that the use of geneticallymodified organisms (GMO) will worsen the current deadly situation. Therefore, to avoid this potential hazard, alternative methods may be necessary to replace the use of antibiotic resistant genes for the purpose of vaccination. Should genetically-modified $L$. lactis be commercialized for disease treatments, the protocols for containment and handling of these strains will also need to be given extra attention. 
Table 1. Examples of clinical and experimental studies using L. lactis as delivery vector for therapeutic purposes.

\begin{tabular}{|c|c|c|c|}
\hline $\begin{array}{l}\text { Target disease } \\
\text { or pathogen }\end{array}$ & Antigen or protein & $\begin{array}{l}\text { Experimental } \\
\text { model }\end{array}$ & Sources \\
\hline \multirow[t]{2}{*}{ Brucella abortus } & $\begin{array}{l}\text { GroEL heat-shock } \\
\text { protein }\end{array}$ & - & (Miyoshi et al., 2014) \\
\hline & $\begin{array}{l}\text { L7/L12 ribosomal } \\
\text { protein }\end{array}$ & $\mathrm{BALB} / \mathrm{c}$ mice & (Pontes et al., 2003) \\
\hline Clostridium tetani & TTFC & C57BL/ 6 mice & $\begin{array}{l}\text { (Norton et al., 1997; Robinson et al., } \\
\text { 2004; Robinson et al., 1997; Steidler } \\
\text { et al., 1998) }\end{array}$ \\
\hline \multirow[t]{3}{*}{ Helicobacter pylori } & UreB & $\begin{array}{l}\mathrm{C} 57 \mathrm{BL} / 6 \text { mice } \\
\mathrm{BALB} / \mathrm{c} \text { mice }\end{array}$ & $\begin{array}{c}\text { (Chen et al., 2006; Lee et al., 2001) } \\
\text { (Zhang et al., 2014) }\end{array}$ \\
\hline & Cag12 & C57BL/ 6 mice & (Kim et al., 2006) \\
\hline & $\mathrm{HpaA}$ and Omp22 & $\mathrm{BALB} / \mathrm{c}$ mice & (Zhang et al., 2016b) \\
\hline Listeria & LLO & $\mathrm{BALB} / \mathrm{c}$ mice & (Bahey-El-Din et al., 2008, 2010) \\
\hline $\begin{array}{l}\text { monocytogenes } \\
\text { Streptococcus } \\
\text { pneumoniae }\end{array}$ & PppA & $\begin{array}{l}\text { Swiss Albino } \\
\text { mice }\end{array}$ & (Medina et al., 2008) \\
\hline \multicolumn{4}{|l|}{ pseudotuberculosis } \\
\hline Leishmania & LACK & $\mathrm{BALB} / \mathrm{c}$ mice & (Hugentobler et al., 2012) \\
\hline $\begin{array}{l}\text { Influenza A } \\
\text { viruses }\end{array}$ & Nucleoprotein & $\mathrm{BALB} / \mathrm{c}$ mice & (Lei et al., 2015) \\
\hline H1N1 & HA1 and nisP & $\mathrm{BALB} / \mathrm{c}$ mice & (Joan et al., 2016) \\
\hline HIV & GAG-p24 antigen & BALB/c mice & (Chamcha et al., 2015) \\
\hline HPV-16 & E7 protein & C57BL/ 6 mice & $\begin{array}{l}\text { (Bermúdez-Humarán et al., 2004, } \\
\text { 2005) }\end{array}$ \\
\hline Rotavirus & $\begin{array}{l}\text { VP8 protein } \\
\text { VP6 protein }\end{array}$ & $\begin{array}{l}\mathrm{BALB} / \mathrm{c} \text { mice } \\
\mathrm{BALB} / \mathrm{c} \text { mice }\end{array}$ & $\begin{array}{l}\text { (Rodríguez-Díaz et al., 2011) } \\
\text { (Esteban et al., 2013) }\end{array}$ \\
\hline Hepatitis C & HCc core antigen & C57BL/ 6 mice & (Parlane et al., 2011) \\
\hline Hepatitis E & ORF2 capsid protein & $\mathrm{BALB} / \mathrm{c}$ mice & (Gao et al., 2015) \\
\hline \multirow{3}{*}{ Cancer } & Endostatin & Wistar rats & (Li and Li, 2005) \\
\hline & Kisspeptin & HT-29 cell line & (Zhang et al., 2016c) \\
\hline & $\begin{array}{c}\text { TRP2-tumor antigen } \\
\text { CEA }\end{array}$ & $\begin{array}{l}\text { CHO-S cell line } \\
\text { BALB / c mice }\end{array}$ & $\begin{array}{l}\text { (Kalyanasundram et al., 2015) } \\
\text { (Zhang et al., 2016a) }\end{array}$ \\
\hline Colitis & Heme-oxygenase 1 & C57BL/ 6 mice & (Shigemori et al., 2015) \\
\hline & Anti-TNF & $\mathrm{BALB} / \mathrm{c}$ mice & (Bernstein et al., 2010) \\
\hline Crohn's disease & IL-4 & $\begin{array}{l}\mathrm{CHO} \text { cells and } \\
\mathrm{BALB} / \mathrm{c} \text { mice }\end{array}$ & (Souza et al., 2016) \\
\hline
\end{tabular}

From the vector aspect, the use of Gram-positive, food-grade $L$. lactis already eliminates the risks surrounding issues with pathogenicity. In general, L. lactis is not known to cause any serious illness in humans. However, its effects on immunocompromised patients are not fully understood, and the risk of sepsis is a primary issue that should be thoroughly considered. In one study, Wagner et al. (1997) demonstrated that several LAB probiotic strains are mainly harmless towards adult immunodeficient mice, showing no signs of mortality or morbidity after 4 to 12 weeks of colonization by probiotic strains. Upon further investigation, $36 \%$ and $21 \%$ of infant mice born to mothers colonized by Lactobacillus casei GG and Lactobacillus renteri, respectively, were found to be dead in less than four weeks. Meanwhile, case reports on two premature infants suffering from sepsis due to Lactobacillus LGG were described by Kunz et al. (2004). In both cases, the infants have 
been previously diagnosed with short bowel syndrome and have received intakes of Lactobacillus LGG probiotic supplements. In a rare event, an otherwise healthy 14-year old girl was diagnosed with mild gastroenteritis and was described as the first reported case of liver abscess as a result of $L$. lactis cremoris (Nakarai et al., 2000). Thus, based on these findings, it can be concluded that although the use of probiotic strains are typically safe on healthy individuals, the risks of infections and side effects may be present in neonatal and immunocompromised patients. Throughout the process of vaccine development, clinical trials, and post-commercialisation, continuous monitoring and evaluation of $L$. lactisbased treatments need to be proceeded with caution to ensure that such incidents could be prevented.

\section{CONCLUSION}

Overall, the identification and characterization of L. lactis have led to significant advancements in its expression and delivery systems. By using $L$. lactis as a model organism, the established genetic tools could be extended to other LAB strains and help refine current vaccination and bacteria-mediated therapeutic strategies. The simplicity and ease of use of $L$. lactis also enable researchers to conduct necessary evaluations on a broad spectrum of diseases and their treatments, with much flexibility. But in order to fully exploit these potentials, several research questions are yet to be answered. Firstly, it would be of interest to determine the rate of DNA or gene transfer that could be achieved when using $L$. lactis as a vector. This information would be significant in order to verify the efficacy of this treatment approach. Once this is understood, various strategies could be designed to enhance the efficiency of gene transfer. Several possible aspects that could be investigated are the dosage, treatment administration route, and mechanisms for achieving targeted delivery. Other than that, it is also important to validate the safety of $L$. lactismediated treatments. Risks of infections and side effects in immunocompromised patients are some of the factors that should be scrutinized and studied over the course of treatment.

\section{ACKNOWLEDGEMENTS}

Hanis Faudzi and Habibah Faroque were supported by Universiti Putra Malaysia (GPIPM/2013/9401700, GP-IPS/2014/9429500, GP/2017/9559200 and GP-IPS/2018/9631500) and Ministry of Education Malaysia (FRGS/2/2013/SG05/UPM/02/13).

\section{REFERENCES}

Abushelaibi, A., Al-Mahadin, S., El-Tarabily, K., Shah, N.P., and Ayyash, M. 2017. "Characterization of potential probiotic lactic acid bacteria isolated from camel milk." $L W T$ - Food Science and Technology 79:316-25.

Agorio, C. et al. 2007. "Live attenuated Salmonella as a vector for oral cytokine gene therapy in melanoma." The Journal of Gene Medicine 9:416-23.

Alegría, Á., S. Delgado, C. Roces, B. López, and B. Mayo. 2010. "Bacteriocins produced by wild Lactococcus lactis strains isolated from traditional, starter-free cheeses made of raw milk." International Journal of Food Microbiology 143(1-2):6166.

Allende, A. et al. 2007. "Growth and bacteriocin production by lactic acid bacteria in vegetable broth and their effectiveness at reducing Listeria monocytogenes in vitro and in fresh-cut lettuce." Food Microbiology 24(7-8):759-66.

Amezquita, A. and Brashears, M. M. 2002. "Competitive inhibition of Listeria monocytogenes in ready-to-eat meat products by lactic acid bacteria." Journal of Food Protection 65(2):316-25.

Bahey-El-Din, M., Casey, P. G., Griffin B. T., and Gahan C. G. M. 2010. "Expression of two Listeria monocytogenes antigens (P60 and LLO) in Lactococcus lactis and examination for use as live vaccine vectors." Journal of Medical Microbiology 59:904-12.

Bahey-El-Din, M., Casey, P. G., Griffin, B. T., and Gahan, C. G. M. 2008. "Lactococcus lactis-expressing listeriolysin O (LLO) provides protection and specific CD8 $+\mathrm{T}$ cells against Listeria monocytogenes in the murine infection model." Vaccine 26:5304-14.

Bermúdez-Humarán, L. G. et al. 2005. "A novel mucosal vaccine based on live lactococci expressing E7 antigen and IL-12 induces systemic and mucosal immune responses and protects mice against human papillomavirus type 16induced tumors." Journal of Immunology 175(11):7297-7302.

Bermúdez-Humarán, L. G. et al. 2004. "An inducible surface presentation system improves cellular immunity against human papillomavirus type 16 E7 antigen in mice after nasal administration with recombinant lactococci." Journal of Medical Microbiology 53(5):427-33.

Bernstein, C., Ho, G. T. and Lees, C. 2010. "Orally administered L. lactis secreting an anti-TNF nanobody demonstrate efficacy in chronic colitis: commentary." Inflammatory Bowel Disease Monitor 10(4):131.

Biscola, V. et al. 2013. "Isolation and characterization of a nisinlike bacteriocin produced by a Lactococcus lactis strain isolated from charqui, a Brazilian fermented, salted and dried meat product." Meat Science 93(3):607-13.

Bolotin, A. et al. 2001. "The complete genome sequence of the lactic acid bacterium." Genome Research 731-53.

Bolotin, A., Mauger, S., Malarme, K., Ehrlich, S. D. and Sorokin, A. 1999. "Low-redundancy sequencing of the entire 
Lactococcus lactis IL1403 genome." Antonie van Leeunenboek 76(1):27-76.

Chamcha, V., Jones, A., Quigley, B. R., Scott, J. R. and Amara. R. R. 2015. "Oral immunization with a recombinant Lactococcus lactis-expressing HIV-1 antigen on group A Streptococcus pilus induces strong mucosal immunity in the gut." Journal of Immunology 195(10):5025-34.

Chen, S., Zhang, R., Duan, G. and Shi, J. 2006. "Food-grade expression of Helicobacter pylori UreB subunit in Lactococcus lactis and its immunoreactivity." Current Microbiology 62(6):462-70.

Daniel, C. et al. 2009. "Protection against Yersinia psendotuberculosis infection conferred by a Lactococcus lactis mucosal delivery vector secreting LcrV." V accine 27:1141-44.

Davison, J. 1999. "Genetic exchange between bacteria in the environment." Plasmid 42:73-91.

Delany, I., Rappuoli, R. and De Gregorio, E. 2014. "Vaccines for the 21 st century." EMBO Mol Med 6:708-20.

Dziewanowska, K. et al. 1999. "Fibronectin binding protein and host cell tyrosine kinase are required for internalization of Staphylococcus aureus by epithelial cells." Infection and Immunity 67(9):4673-78.

Esteban, L. E., Temprana, C. F., Argüelles, M. H., Glikmann, G. and Castello, A. A. 2013. "Antigenicity and immunogenicity of rotavirus VP6 protein expressed on the surface of Lactococcus lactis." BioMed Research International 2013.

Fernández, E., Alegría, A., Delgado, S., Martín, M. C. and Mayo, B. 2011. "Comparative phenotypic and molecular genetic profiling of wild Lactococcus lactis subsp. lactis strains of the L. lactis subsp. lactis and L. lactis subsp. cremoris genotypes, isolated from starter-free cheeses made of raw milk." Applied and Environmental Microbiology 77(15):5324-35.

Flahaut, N. A. L. et al. 2013. "Genome-scale metabolic model for Lactococcus lactis MG1363 and its application to the analysis of flavor formation." Applied Microbiology and Biotechnology 97(19):8729-39.

Galmbacher, K. et al. 2010. "Shigella mediated depletion of macrophages in a murine breast cancer model is associated with tumor regression." PLOS ONE 5(3):1-11.

Gao, S. et al. 2015. "Oral immunization with recombinant hepatitis E virus antigen displayed on the Lactococcus lactis surface enhances ORF2-specific mucosal and systemic immune responses in mice." International Immunopharmacology 24(1):140-45.

Gao, Y. et al. 2011. "Complete genome sequence of Lactococcus lactis subsp. lactis CV56, a probiotic strain isolated from the vaginas of healthy women." JOURNAL OF BACTERIOLOGY 193(11):2886-87.

Goldin, B. R. et al. 1992. "Survival of Lactobacillus species (strain GG) in human gastrointestinal tract." Digestive Diseases and Sciences 37(1):121-28.

Grahn, E., Holm, S. E., Lilja, H. and Sellgren K. 1994. "Interference of a Lactococcus lactis strain on the human gut flora and its capacity to pass the stomach and intestine." Scandinavian Journal of Nutrition.

Guedon, E., Sperandio, B., Pons, N., Ehrlich, S. D. and Renault, P. 2005. "Overall control of nitrogen metabolism in Lactococcus lactis by CodY, and possible models for CodY regulation in Firmicutes." Microbiology 151(12):3895-3909.

Guo, X-H., Kim, J-M., Nam, H-M., Park, S-Y. and Kim, J-M. 2010. "Screening lactic acid bacteria from swine origins for multistrain probiotics based on in vitro functional properties." Anaerobe 16(4):321-26.

Hirsch, A. 1951. "Growth and nisin production of a strain of Streptococcus lactis." J Gen Microbiol 5:208-21.

Holo, H., Nilssen, Ø. and Nes, I. F. 1991. "Lactococcin A, a new bacteriocin from Lactococcus lactis subsp. cremoris: isolation and characterization of the protein and its gene." Journal of
Bacteriology 173(12):3879-87.

Hugentobler, F., Di Roberto, R. B., Gillard, J. and Cousineau, B. 2012. "Oral immunization using Lactococcus lactis coexpressing LACK and IL-12 protects BALB/c mice against Leishmania major infection." Vaccine 30:5726-32.

Innocentin, S. et al. 2009. "Lactococcus lactis expressing either Staphylococcus aureus fibronectin-binding protein A or Listeria monocytogenes internalin A can efficiently internalize and deliver DNA in human epithelial cells." Applied and Environmental Microbiology 75(14):4870-78.

Iwaki, M. et al. 1990. "Oral immunization with recombinant Streptococcus lactis carrying the Streptococcus mutans surface protein antigen gene." Infection and Immunity 58(9):2929-34.

Jacobsen, C. N. et al. 1999. "Screening of probiotic activities of forty-seven strains of Lactobacillus spp. by in vitro techniques and evaluation of the colonization ability of five selected strains in humans." Applied and Environmental Microbiology 65(11):4949-56.

Joan, S. S. X. et al. 2016. "Oral vaccine of Lactococcus lactis harbouring pandemic H1N1 2009 haemagglutinin1 and nisP anchor fusion protein elevates anti-HA1 sIgA levels in mice.” Biotechnology Letters 38(5):793-99.

Kalyanasundram, J. et al. 2015. "Surface display of glycosylated tyrosinase related protein-2 (TRP-2) tumour antigen on Lactococcus lactis." BMC Biotechnology 15(1):113.

Kamal, N. M., Zamri-Saad, M., Masarudin, M. J. and Othman, S. 2017. "Interaction between Pasteurella multocida B:2 and its derivatives with bovine aortic endothelial cell (BAEC)." BMC Veterinary Research 13(1):186.

Kandler, O. 1983. "Carbohydrate metabolism in lactic acid bacteria." Antonie van Leeuwenhoek 49(3):209-24.

Kim, J. Y., Young, J. A., Gunther, N. W. and Lee, J-L. 2015. "Inhibition of Salmonella by bacteriocin-producing lactic acid bacteria derived from U.S. kimchi and broiler chicken." Journal of Food Safety 35(1):1-12.

Kim, S-J., Jun, D. Y., Yang, C. H. and Kim, Y. H. 2006. "Expression of Helicobacter pylori cag12 gene in Lactococcus lactis MG1363 and its oral administration to induce systemic anti-Cag12 immune response in mice." Appl Microbiol Biotechnol 72:462-70.

Kimoto, H., Kurisaki, J., Tsuji, N. M., Ohmomo, S. and Okamoto, T. 1999. "Lactococci as probiotic strains: adhesion to human enterocyte-like Caco-2 cells and tolerance to low $\mathrm{pH}$ and bile." Letters in Applied Microbiology 29(5):313-16.

Klijn, N., Weerkamp, A. H. and de Vos, W. M. 1995. "Genetic marking of Lactococcus lactis shows its survival in the human gastrointestinal tract." Applied and Environmental Microbiology 61(7):2771-74

Kolida, S. and Gibson, G. R. 2011. "Synbiotics in health and disease." Annu. Rev. Food Sci. Technol 2:373-93.

Konings, W. 2000. "Lactic acid bacteria: the bugs of the new millennium." Current Opinion in Microbiology 3(3):276-82.

Kuipers, O. P., Beerthuyzen, M. M., Siezen, R. J. and de Vos, W. M. 1993. "Characterization of the nisin gene cluster nisABTCIPR of Lactococcus lactis. Requirement of expression of the nisA and nisI genes for development of immunity." European Journal of Biochemistry 216(1):281-91.

Kuipers, O. P. et al. 1998. "Quorum sensing-controlled gene expression in lactic acid bacteria." Journal of Biotechnology 64(1):15-21.

Kunz, A. N., Noel, J. M. and Fairchok, M. P. 2004. "Two cases of Lactobacillus bacteremia during probiotic treatment of short gut syndrome." (April):457-58.

Lecuit, M., Ohayon, H., Braun, L., Mengaud, J. and Cossart, P. 1997. "Internalin of Listeria monocytogenes with an intact leucine-rich repeat region is sufficient to promote internalization." Infection and Immunity 65(12):5309-19.

Lee, M. H., Roussel, Y., Wilks, M. and Tabaqchali, S. 2001. 
"Expression of Helicobacter pylori urease subunit B gene in Lactococcus lactis MG1363 and its use as a vaccine delivery system against $H$. pylori infection in mice." V accine 19:392735.

Lehto, E. M. and Salminen, S. 1997. “Adhesion of two Lactobacillus strains, one Lactococcus and one Propionibacterium strain to cultured human intestinal Caco-2 cell line." Bioscience Microflora 16(1):13-17.

Lei, H., Peng, X., Jiao, H., Zhao, D. and Ouyang, J. 2015. "Broadly protective immunity against divergent influenza viruses by oral co-administration of Lactococcus lactis expressing nucleoprotein adjuvanted with cholera toxin B subunit in mice." Microbial Cell Factories 14(1):111.

Leroy, F. and de Vuyst, L. 2004. "Lactic acid bacteria as functional starter cultures for the food fermentation industry." Trends in Food Science \& Technology 15(2):67-78.

Li, W. and Li, C-B. 2005. "Effect of oral Lactococcus lactis containing endostatin on 1, 2-dimethylhydrazine-induced colon tumor in rats." World Journal of Gastroenterology : WJG 11(46):724247.

Lilly, D. M. and Stillwell, R. H. 1965. "Probiotics: growthpromoting factors produced by microorganisms." Science 147(3659):747-48.

Martín, R. et al. 2014. "Effects in the use of a genetically engineered strain of Lactococcus lactis delivering in situ IL-10 as a therapy to treat low-grade colon inflammation." Human V accines and Immunotherapeutics 10(6):1611-21.

Mclaughlin-drubin, M. E. and Münger, K. 2009. "The human papilloma virus E7 oncoprotein." Virology 384(2):335-44.

Medina, M. et al. 2008. "Nasal immunization with Lactococcus lactis expressing the pneumococcal protective protein A anduces protective immunity in mice." Infection and Immunity 76(6):2696-2705.

Miyoshi, A. et al. 2014. "Heterologous expression of Brucella abortus GroEL heat-shock protein in Lactococcus lactis.” Pathogens and Diseases 72(1):78-86.

Mowday, A. M. et al. 2016. "Advancing Clostridia to clinical trial: past lessons and recent progress." Cancers $8(7)$.

Nakarai, T., Morita, K., Nojiri, Y., Nei, J. and Kawamori, Y. 2000. "Liver abscess due to Lactococcus lactis cremoris." Pediatrics International 42(6):699-701.

Nissen-meyer, J., Holo, H. and Havarstein, L. S. 1992. "A novel Lactococcal bacteriocin whose activity depends on the complementary action of two peptides." Journal of Bacteriology 174(17):5686-92.

Norton, P. M., Wells, J. M., Brown, H. W. G., Macpherson A. M., and Le Page, R. F. W. 1997. "Protection against tetanus toxin in mice nasally immunized with recombinant Lactococcus lactis expressing tetanus toxin fragment C." Vaccine 15(6/7):616-19.

Okuda, K-I. et al. 2013. "Effects of bacteriocins on methicillinresistant Staphylococcus aureus biofilm." Antimicrobial Agents Chemotherapy 57:5572-79.

Oliveira, A., Nielsen, J. and Förster, J. 2005. "Modeling Lactococcus lactis using a genome-scale flux model." BMC Microbiology 5(1):39.

Oozeer, R. et al. 2006. "Survival of Lactobacillus casei in the human digestive tract after consumption of fermented milk." Applied and Environmental Microbiology 72(8):5615-17.

Othman, S., Parton, R. and Coote, J. 2012. "Interaction between mammalian cells and Pasteurella multocida B:2. Adherence, invasion and intracellular survival." Microbial Pathogenesis 52(6):353-58.

Ouwehand, A. C., Kirjavainen, P. V., Grönlund, M. M., Isolauri, E. and Salminen, S. J. 1999. "Adhesion of probiotic microorganisms to intestinal mucus." International Dairy Journal 9:623-30

Pálffy, R. et al. 2006. "Bacteria in gene therapy: bactofection versus alternative gene therapy." Gene Therapy 13(2):101-5.

Parlane, N. A. et al. 2011. "Production of a particulate hepatitis C vaccine candidate by an engineered Lactococcus lactis strain." Applied and Environmental Microbiology 77(24):8516-22.

Perin, L. and Nero, L. 2014. "Antagonistic lactic acid bacteria isolated from goat milk and identification of a novel nisin variant Lactococcus lactis." BMC Microbiology 14(1):36.

van Pijkeren, J. P. et al. 2010. "A novel Listeria monocytogenes-based DNA delivery system for cancer gene therapy.” Human Gene Therapy 21(4):405-16.

Pilgrim, S. et al. 2003. "Bactofection of mammalian cells by Listeria monocytogenes: improvement and mechanism of DNA delivery." Gene Therapy 10(24):2036-45.

Pontes, D. S. et al. 2003. "Induction of partial protection in mice after oral administration of Lactococcus lactis producing Brucella abortus L7/L12 antigen." Journal of Drug Targeting 11(8-10):489-93.

Richardson, M. A., Ramirez, T., Russell, N. C. and Moye, L. A. 1999. "Coley toxins immunotherapy: A retrospective review." Alternative Therapies in Health and Medicine 5(3):4247.

Robinson, K. et al. 2004. "Mucosal and cellular immune responses elicited by recombinant Lactococcus lactis strains expressing tetanus toxin fragment C." Infection and Immunity 72(5):275361.

Robinson, K., Chamberlain, L. M., Schofield, K. M., Wells, J. M. and Le Page, R. W. F. 1997. "Oral vaccination of mice against tetanus with recombinant Lactococcus lactis." Nature Biotechnology 15(7):653-57.

Rodríguez-Díaz, J. et al. 2011. "Oral immunization of mice with Lactococcus lactis expressing the rotavirus VP8 protein." Biotechnology Letters 33(6):1169-75.

Rubio, R., Jofré, A., Martín, B., Aymerich, T. and Garriga, M. 2014. "Characterization of lactic acid bacteria isolated from infant faeces as potential probiotic starter cultures for fermented sausages." Food Microbiology 38:303-11.

Rubio, R., Martín, B., Aymerich, T. and Garriga, M. 2014. "The potential probiotic Lactobacillus rhamnosus CTC1679 survives the passage through the gastrointestinal tract and its use as starter culture results in safe nutritionally enhanced fermented sausages." International Journal of Food Microbiology 186:55-60.

Rueda, F. et al. 2014. "Production of functional inclusion bodies in endotoxin-free Escherichia coli." Applied Microbiology and Biotechnology 98(22):9229-38.

de Ruyter, P. G., Kuipers, O. P., Beerthuyzen, M. M., Van AlenBoerrigter, I. and de Vos, W. M. 1996. "Functional analysis of promoters in the nisin gene cluster of Lactococcus lactis." Journal of Bacteriology 178(12):3434-39.

de Ruyter, P. G., Kuipers, O. P. and de Vos, W. M. 1996. "Controlled gene expression systems for Lactococcus lactis with the food-grade inducer nisin." Applied and Environmental Microbiology 62(10):3662-67.

Salminen, S. et al. 1998. "Demonstration of safety of probiotics -a review." International Journal of Food Microbiology 44(1-2):93106.

Salminen, S., Ouwehand, A., Benno, Y. and Lee, Y. K. 1999. "Probiotics: how should they be defined?" Trends in Food Science \& Technology 107-10.

Sashihara, T. et al. 2000. "A novel lantibiotic, nukacin ISK-1, of Staphylococcus warneri ISK-1: cloning of the structural gene and identification of the structure." Bioscience, Biotechnology, and Biochemistry 64(11):2420-28.

Sawa, N. et al. 2013. "Identification and characterization of novel multiple bacteriocins produced by Lactobacillus sakei D98." Journal of Applied Microbiology 115(1):61-69.

Sawa, N. et al. 2010. "Identification and characterization of novel multiple bacteriocins produced by Leuconostoc 
psendomesenteroides QU15.” Journal of Applied Microbiology 109(1):282-91.

Schlundt, J., Saadbye, P., Lohmann, B., Jacobsen, B. L. and Nielsen, E. M. 1994. "Conjugal transfer of plasmid DNA between Lactococcus lactis strains and distribution of transconjugants in the digestive tract of gnotobiotic rats." Microbial Ecology in Health and Disease 7 (2):59-69.

Schrezenmeir, J. and de Vrese, M. 2001. "Probiotics, prebiotics, and synbiotics-approaching a definition." Food Biotechnology 73(2):361S-364S.

Settanni, L. and Moschetti, G. 2010. "Non-starter lactic acid bacteria used to improve cheese quality and provide health benefits." Food Microbiology 27(6):691-97.

Shigemori, S. et al. 2015. "Oral delivery of Lactococcus lactis that secretes bioactive heme oxygenase- 1 alleviates development of acute colitis in mice." Microbial Cell Factories 14(1):189.

Shigemori, S. et al. 2017. "Secretion of an immunoreactive singlechain variable fragment antibody against mouse interleukin 6 by Lactococcus lactis." Applied Microbiology and Biotechnology 101(1):341-49.

Siezen, R. J. et al. 2010. "Complete genome sequence of Lactococcus lactis subsp. lactis KF147, a plant-associated lactic acid bacterium." Journal of Bacteriology 192(10):2649-50.

Souza, B. M. et al. 2016. "Lactococcus lactis carrying the pValac eukaryotic expression vector coding for IL-4 reduces chemically-induced intestinal inflammation by increasing the levels of IL-10-producing regulatory cells." Microbial Cell Factories 15(1):150.

Steidler, L. et al. 1998. "Mucosal delivery of murine interleukin-2 (IL-2) and IL-6 by recombinant strains of Lactococcus lactis coexpressing antigen and cytokine." Infection and Immunity 66(7):3183-89.

Stevens, K. A., Sheldon, B. W., Klapes, N. A. and Klaenhammer, T. R. 1991. "Nisin treatment for inactivation of Salmonella species and other Gram-negative bacteria." Applied and Environmental Microbiology 57(12):3613-15.

Stiles, M. E. and Holzapfel, W. H. 1997. "Lactic acid bacteria of foods and their current taxonomy." International Journal of Food Microbiology 36(1):1-29.

Teuber, M. and Geis, A. 2006. “The genus Lactococcus." pp. 205-28 in The Prokaryotes. New York, NY: Springer US.

Wagner, R. D., Warner, T., Roberts, L., Farmer, J. and Balish, E. 1997. "Colonization of congenitally immunodeficient mice with probiotic bacteria." Infection and Immunity 65(8):334551.

Wegmann, U. et al. 2007. "Complete genome sequence of the prototype lactic acid bacterium Lactococcus lactis subsp. cremoris MG1363." Journal of Bacteriology 189(8):3256-70.

Yagnik, B., Padh, H. and Desai, P. 2016. "Construction of a new shuttle vector for DNA delivery into mammalian cells using non-invasive Lactococcus lactis." Microbes and Infection 18(4):237-44.

Yagnik, B., Sharma, D., Padh, H. and Desai, P. 2017. "Dual recombinant Lactococcus lactis for enhanced delivery of DNA vaccine reporter plasmid pPERDBY." Microbiology and Immunology 61(3-4):123-29.

Yang, Y. et al. 2010. "Oral vaccination with Ts87 DNA vaccine delivered by attenuated Salmonella typhimurium elicits a protective immune response against Trichinella spiralis larval challenge." Vaccine 28(15):2735-42.

Zhang, B. et al. 2016c. "Recombinant Lactococcus lactis NZ9000 secretes a bioactive kisspeptin that inhibits proliferation and migration of human colon carcinoma HT-29 cells." Microbial Cell Factories 15(1):102.

Zhang, H. et al. 2014. "Immunogenicity of oral vaccination with Lactococcus lactis derived vaccine candidate antigen (UreB) of Helicobacter pylori fused with the human interleukin 2 as adjuvant." Molecular and Cellular Probes 28:25-30.

Zhang, R. et al. 2016b. "Construction of a recombinant Lactococcus lactis strain expressing a fusion protein of Omp22 and $\mathrm{HpaA}$ from Helicobacter pylori for oral vaccine development." Biotechnology Letters 38(11):1911-16.

Zhang, X. et al. 2016a. "Heterologous expression of carcinoembryonic antigen in Lactococcus lactis via LcsBmediated surface displaying system for oral vaccine development." Journal of Microbiology, Immunology and Infection 49(6):851-58.

Zoumpopoulou, G. et al. 2017. "Probiotic features of lactic acid bacteria isolated from a diverse pool of traditional Greek dairy products regarding specific strain-host interactions." Probiotics and Antimicrobial Proteins 1-10. 